\title{
Аналіз паливної ефективності глибокого охолодження повітря на вході газотурбінної установки в різних кліматичних умовах
}

\author{
А. М. Радченко ${ }^{1}$ Я. Зонмін ${ }^{2}$, С. А. Кантор ${ }^{3}$, Б. С. Портной \\ ${ }^{1}$ Національний університет кораблебудування ім. адм. Макарова, м. Миколаїв, 54002, Україна \\ ${ }^{2}$ Цзянсуньський університет науки і технології, м. Чженьцзян, КНР \\ ${ }^{3}$ ПАТ "Завод "Екватор", м. Миколаїв, Україна
}

\begin{abstract}
Проаналізовано паливну ефективність глибокого охолодження повітря на вході газотурбінної установки (ГТУ) при для кліматичних умов півдня України (регіон м. Одеса) та субтропічного клімату КНР (на прикладі м. Чженьизян, провіниія Цзянсу). Досліджено ефективність двоступеневого охолодження повітря на вході газотурбінної установки: попереднього охолодження зовнішнього повітря холодною водою з температурою $7^{\circ} \mathrm{C}$ від абсорбиійної бромистолітієвої холодильної машини (АБХМ) до температури $15^{\circ} \mathrm{C}$ у першому високотемпературному ступені повітроохолоджувача та наступного більш глибокого його доохолодження до температури $10^{\circ} \mathrm{C}$ у другому низькотемпературному ступені киплячим хладоном від ежекторної холодильної машини (ЕХM), як конструктивно найбільш прості і надійні в експлуатації. При ицьому як абсорбційна бромистолітієва холодильна машина, так і хладонова ежекторна машина використовують для отримання холоду теплоту відпраџьованих газів газотурбінної установки. В якості критерія застосовано питому витрату палива. Ефективність глибокого охолодження повітря на вході газотурбінної установки аналізували як за поточними величинами зменшення питомої витрати палива упродовж року при змінних кліматичних умовах експлуатації, так $i$ за накопиченням щомісячно та за рік. Показано, шьо більш глибоке охолодження повітря на вході ГТУ до температури $10{ }^{\circ} \mathrm{C}$ в ЕХМ забезпечує зменшення витрати палива у півтора-два рази завдяки взаємно пов'язаному подвійному ефекту: збільшенню самої величини зниження температури повітря $\Delta t_{10}$ до $10^{\circ} \mathrm{C}$ за рахунок обумовленого нею ж зростання тривалості охолоджувального сезону на 20...30\% порівняно з традиційним охолодженням повітря до температури $15{ }^{\circ} \mathrm{C}$ в АБХМ. Результати аналізу паливної ефективності застосування двоступеневого охолодження повітря в украй напружених тепловологісних умовах, зокрема субтропічного клімату, дають підстави для розширення географії застосування глибокого охолодження повітря й на регіони, в яких найбільш поширене традиційне охолодження повітря в АБХМ, а застосування контактних методів зниження температури повітря упорскуванням води не дає бажаного ефекту через високу вологість повітря.
\end{abstract}

Ключові слова: Охолодження повітря; Холодильна машина; Газотурбінна установка; Клімат.

(C) The Author(s) 2018. This article is an open access publication

This work is licensed under the Creative Commons Attribution 4.0 International License (CC BY) http://creativecommons.org/licenses/by/4.0/

\section{1. Вступ}

Підвищення паливної ефективності газотурбінних установок (ГТУ) при високих температурах зовнішнього повітря $t_{3 п}$ на вході шляхом його охолодження один $з$ основних напрямів в енергетиці багатьох країн світу [1-3]. На жаль, в Україні, газотранспортна система якої є однією з найбільш розгалужених в Європі та світі, належного розвитку цей напрям не отримав і досі. В той же час в сусідній Білорусії, навіть за більш прохолодного клімату, приклади модернізації існуючих газотурбокомпресорних станцій шляхом впровадження охолодження повітря на вході ГТУ не поодинокі. В ряді публікацій, зокрема $[4,5]$, автори показали, що і в умовах помірного клімату, характерного для України та країн Європи, саме більш глибоке охолодження повітря на вході ГТУ до $10^{\circ} \mathrm{C}$ і нижче забезпечує у $1,5-2$ рази більшу економію палива порівняно 3 традиційним його охолодженням абсорбційними бромистолітієвими холодильними машинами (АБХМ). Запропоновано також і системи двоступеневого охолодження повітря з використанням у якості низькотемпературного ступеня хладонового охолоджувача повітря 3 холодопостачанням від ежекторної холодильної машини (ЕХМ) як конструктивно набільш простої, відповідно й надійної в експлуатації. В якості ж високотемпературного ступеня охолодження зовнішнього повітря до $15^{\circ} \mathrm{C}$ застосовується традиційна АБХМ $[4,5]$. Аналіз паливної ефективності застосування двоступеневого охолодження повітря в украй напружених тепловологісних умовах, зокрема субтропічного клімату, дає можливість розширити географію застосування глибокого охолодження повітря й на регіони, в яких найбільш поширене традиційне охолодження в АБХМ, а застосування контактного охолодження повітря упорскуванням води не дає бажаного ефекту через високу вологість повітря.

Мета роботи - дослідження паливної ефективності глибокого охолодження повітря на вході ГТУ тепловикористовуючими холодильними машинами комбінованого типу в різних кліматичних умовах.

\section{2. Результати дослідження}

При експлуатації ГТУ параметри зовнішнього повітря (температура $t_{3 п}$, відносна вологість $\varphi_{3 п}$, вологовміст $\left.d_{3 п}\right)$ суттєво змінюються. На рис. 1 наведено їх 
зміну упродовж 2017 року для м. Одеса, Україна, та м. Чженьцзян, провінція Цзянсу, КНР.

Особливістю кліматичних умов півдня КНР є великі відносна вологість повітря $\varphi_{з п}$, відповідно й вологовміст $d_{3 п}$ при водночас високих його температурах $t_{3 п}$ (рис. 1,б). Це свідчить про великі теплові наванта- ження (витрати холодопродуктивності ТХМ) на систему охолодження повітря на вході ГТУ, зумовлені значною часткою прихованої теплоти конденсації водяної пари з повітря, на відведення якої витрачається більша частина холодопродуктивності ТХМ.
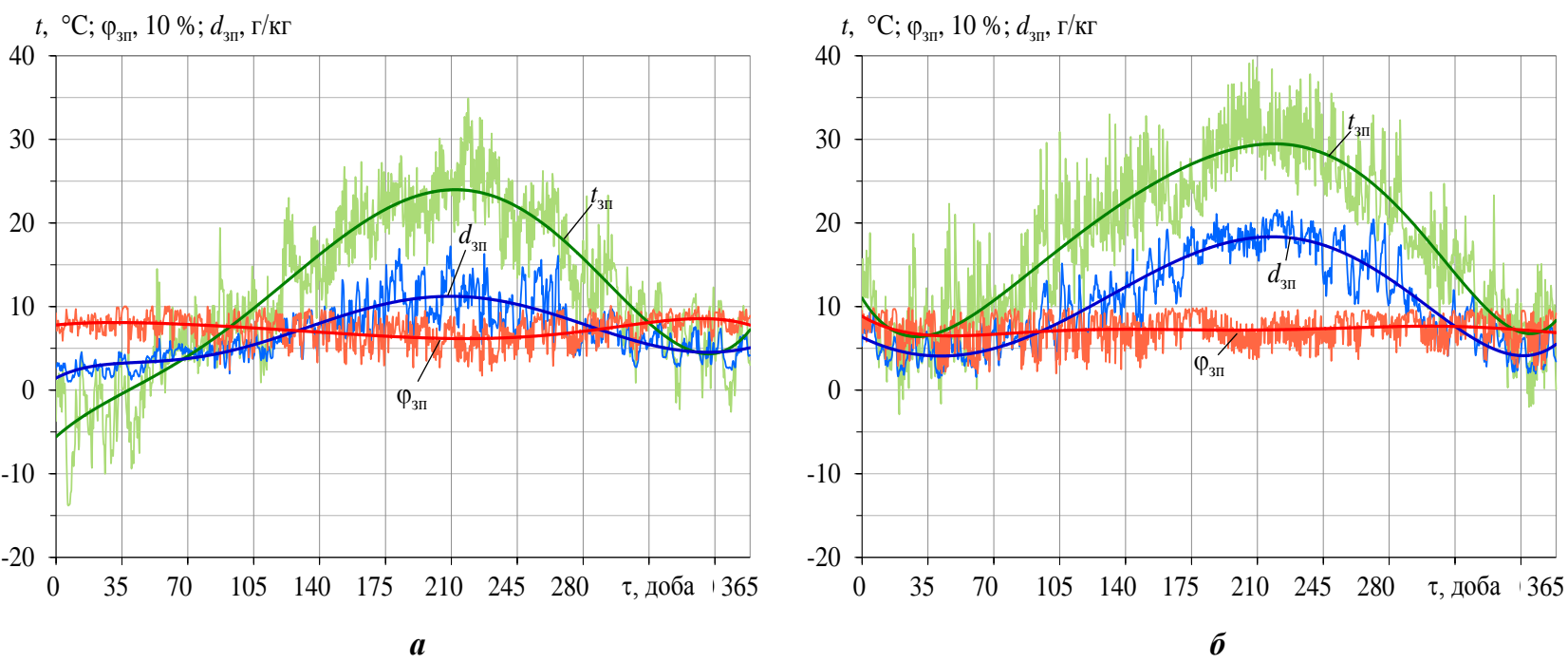

Рисунок 1 - Поточні значення температури $t_{3 n}$, відносної вологості $\varphi_{3 n}$ та вологовмісту $d_{3 n}$ зовнішнього повітря у 2017 рочі: $\boldsymbol{a}$-м. Одеса, Одеська область, Украӥна; б-м. Чженьизян, провінція Цзянсу, КНР

Для охолодження зовнішнього повітря до температури $t_{\text {п2 }}=15^{\circ} \mathrm{C}$ на вході ГТУ застосовано АБХМ, а для більш глибокого охолодження повітря - двоступеневу абсорбційно-ежекторну холодильну машину (AЕХМ) 3 АБХМ в якості високотемпературного ступеня попереднього охолодження зовнішнього повітря до температури $t_{\text {п2 }}=15^{\circ} \mathrm{C}$ та хладоновою ЕХМ подальшого глибокого охолодження до $10^{\circ} \mathrm{C}$ і нижче) $[4,5]$.

Про поточне упродовж року зменшення питомої витрати палива $\Delta b_{e 15}$ за рахунок охолодження повітря на вході ГТУ від $t_{3 п}$ до $t_{\text {п2 }}=15^{\circ} \mathrm{C}$ за 2017 рік для умов м. Одеса, Україна, та м. Чженьцзян, КНР, можна судити за рис. 2, а про скорочення питомої витрати палива $\Delta b_{e 10}$ при більш глибокому охолодженні повітря на вході ГТУ від $t_{3 п}$ до $t_{\text {п2 }}=10^{\circ} \mathrm{C}-$ за рис. 3. Розрахунки виконані, виходячи зі зменшення питомої витрати палива $\Delta b_{e}$ на 0,7 г/(кВт·год) при зниженні температури повітря $\Delta t_{\text {п }}$ на $1^{\circ} \mathrm{C}[6]$.
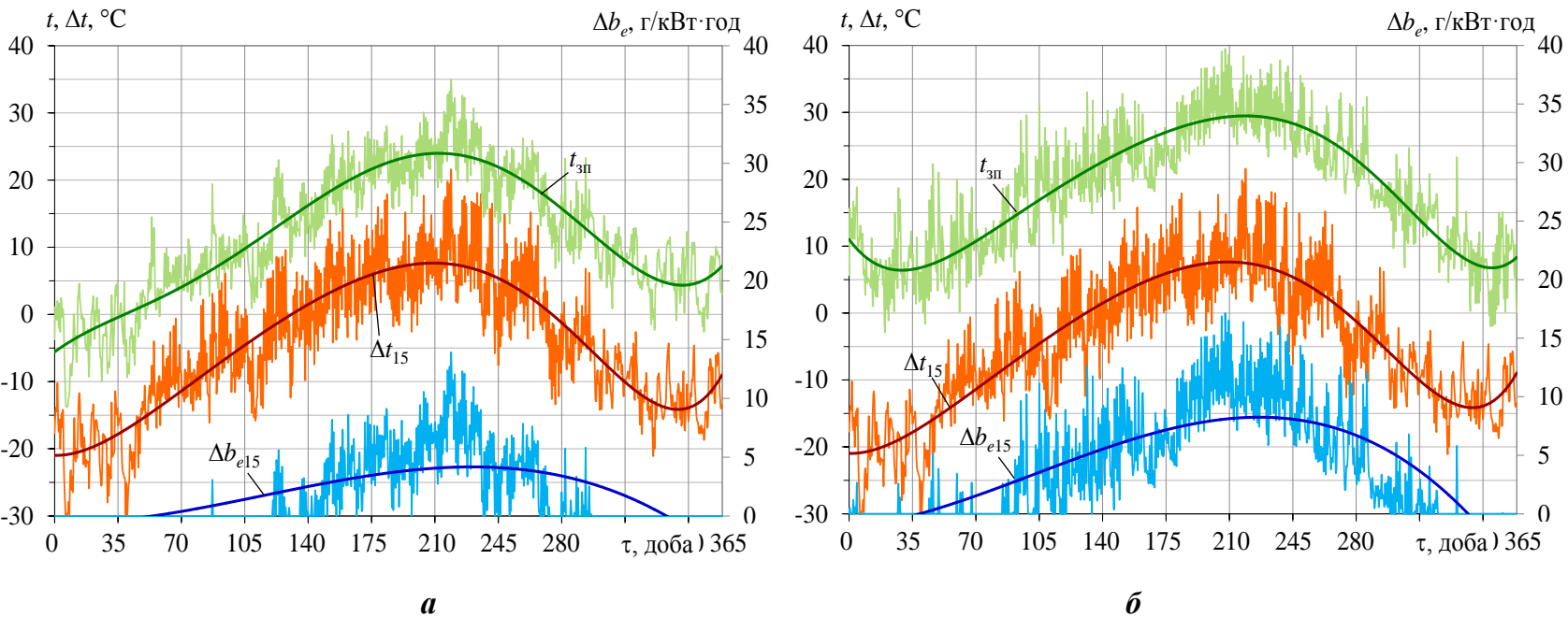

Рисунок 2 - Поточні значення температури $t_{3 n}$ зовнішнього повітря, зниження температури $\Delta t_{15}$ зовнішнього повітря при його охолодженні до $t_{n 2}=15^{\circ} \mathrm{C}$ в АБХМ та відповідного зменшення питомої витрати палива $\Delta b_{e 15}$ за 2017 рік: $\boldsymbol{a}$-м. Одеса, Україна; б-м. Чженьцзян, провінція Цзянсу, КНР 


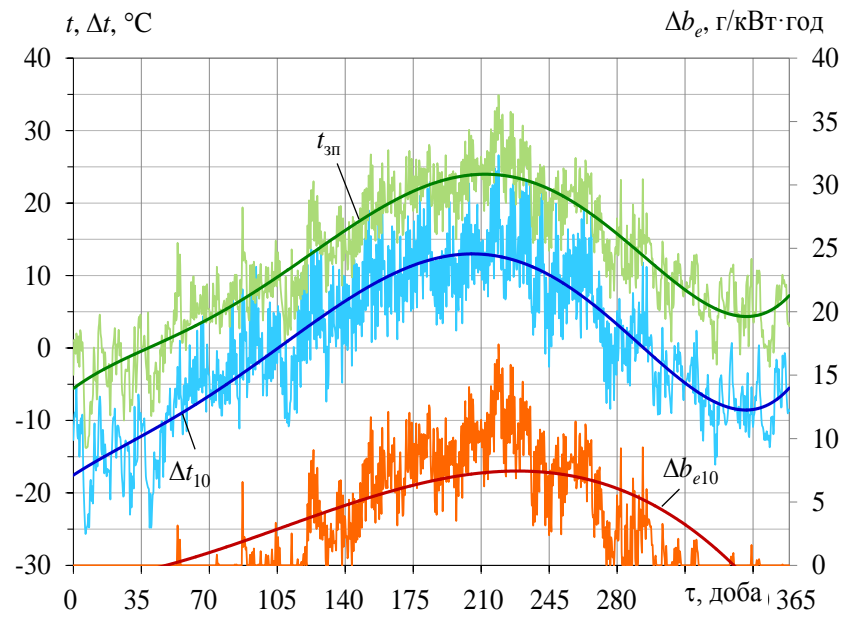

$\boldsymbol{a}$

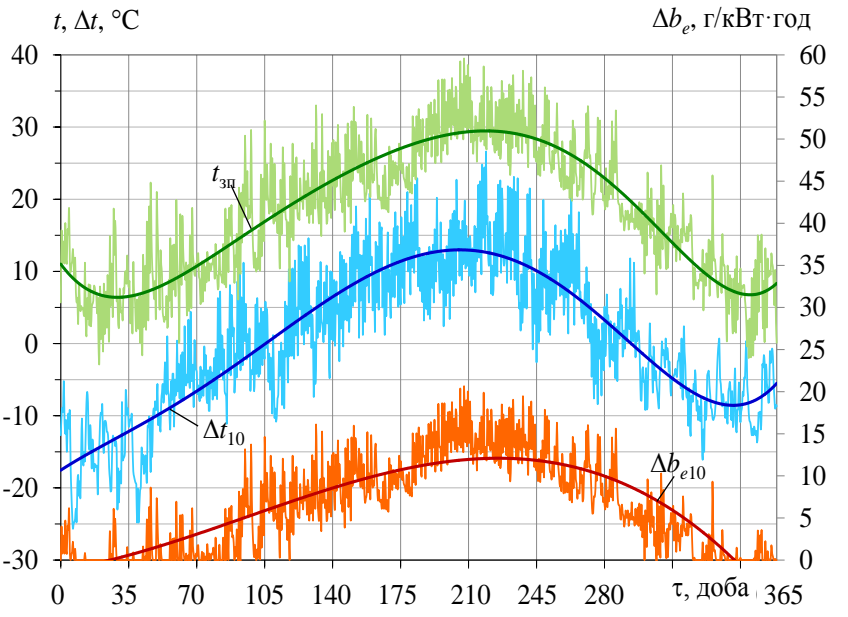

б

Рисунок 3 - Поточні значення температури $t_{3 n}$ зовнішнього повітря, зниження температури $\Delta t_{10}$ зовнішнього повітря при його охолодженні до $t_{n 2}=10^{\circ} \mathrm{C}$ в АЕХМ та відповідного зменшення питомої витрати палива

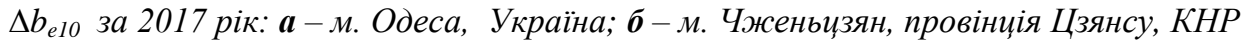

Як видно, більш глибоке охолодження повітря на вході ГТУ до температури $t_{\text {п2 }}=10^{\circ} \mathrm{C}$ в АЕХМ забезпечує поточне зменшення питомої витрати палива $\Delta b_{e 10}$ на $7 \ldots 15$ г/(кВт.год), причому завдяки взаємно пов'язаному подвійному ефекту: збільшенню самої величини зниження температури повітря $\Delta t_{10}$ завдяки обумовленого нею ж зростанню тривалості охолоджувального сезону з приблизно 6 і до майже 9 місяців при охолодженні повітря відповідно до температури $t_{\text {п2 }}=15$ і $10{ }^{\circ} \mathrm{C}$. Слід зазначити, що реальна економія палива буде дещо меншою через витрати потужності ГТУ, відповідно й палива, на подолання аеродинамічного опору повітроохолоджувача на вході.

Більш глибоке охолодження повітря на вході ГТУ до температури $t_{\text {п2 }}=10^{\circ} \mathrm{C}$ в AEXM забезпечує сумарне за липень зменшення питомої витрати палива $\Sigma \Delta b_{e_{1} 10}$ близько 6,6 кг/кВт (віднесене до 1 кВт потужності ГТУ) для кліматичних умов м. Одеса, Україна (рис.4, a) і близько 11 кг/кВт для кліматичних умов м. Чженьцзян, КНР (рис.4, б). При цьому застосування глибокого охолодження повітря до температури $t_{\text {п2}}=10^{\circ} \mathrm{C}$ в AEXM у порівнянні 3 охолодженням в АБХМ до $t_{\text {п2 }}=15^{\circ} \mathrm{C}$ дає більший ефект для кліматичних умов України, ніж в умовах вологого клімату КНР (рис. 4).

Економія палива $b_{e}$ помісячно та за 2017 рік за рахунок охолодження повітря на вході ГТУ від поточної

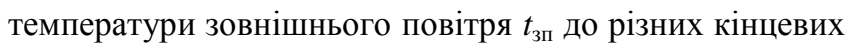

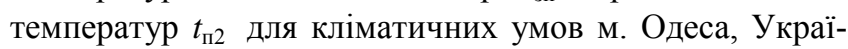
на, та м. Чженьцзян, КНР, наведена на рис. 5.

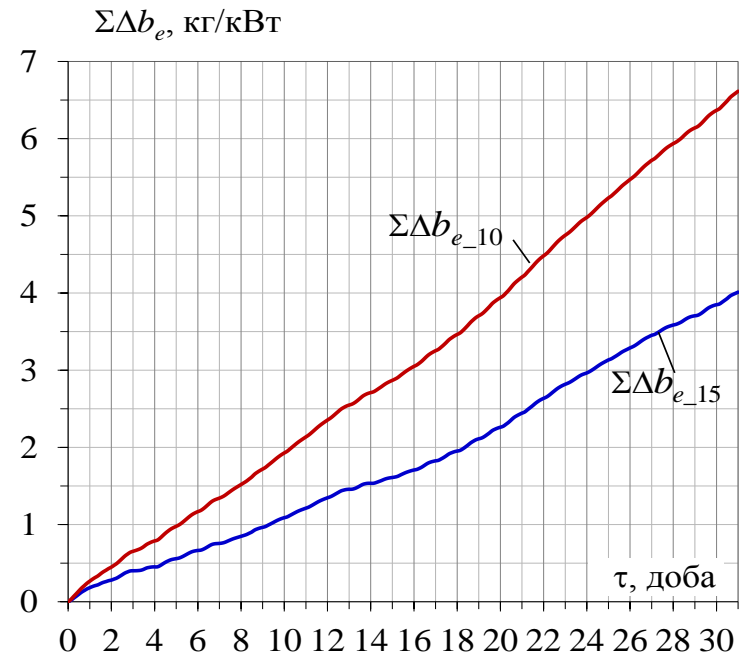

$a$

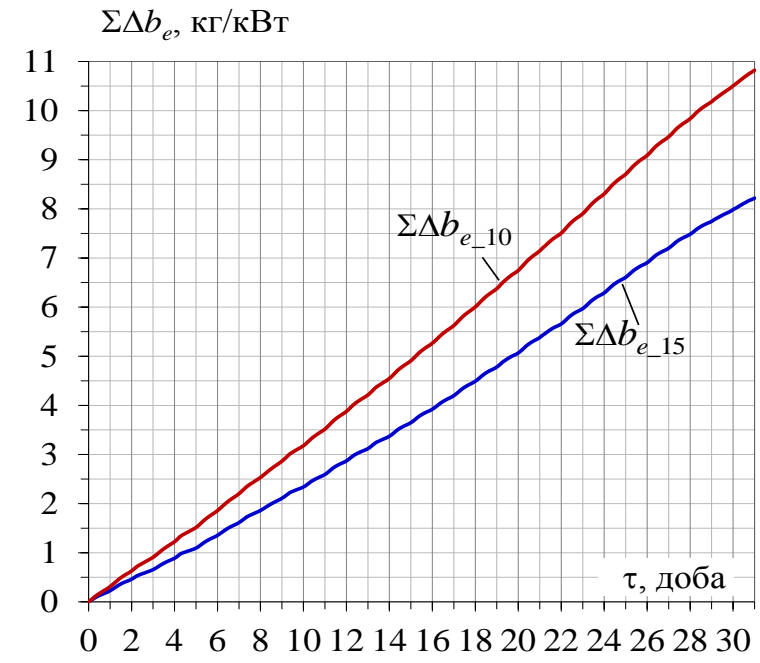

б

Рисунок 4 - Значення загальної за місяиь $\Sigma \Delta b_{e}$ економії палива при різних температурах охолодженого повітря $t_{n 2}: 10{ }^{\circ} \mathrm{C}-A E X M ; 15^{\circ} \mathrm{C}-A Б Х М$ за липень 2017 p.; $\boldsymbol{a}-$ м. Одеса, Україна; $\boldsymbol{\sigma}-$ м. Чженьизян, провіниія Цзянсу, КНР 

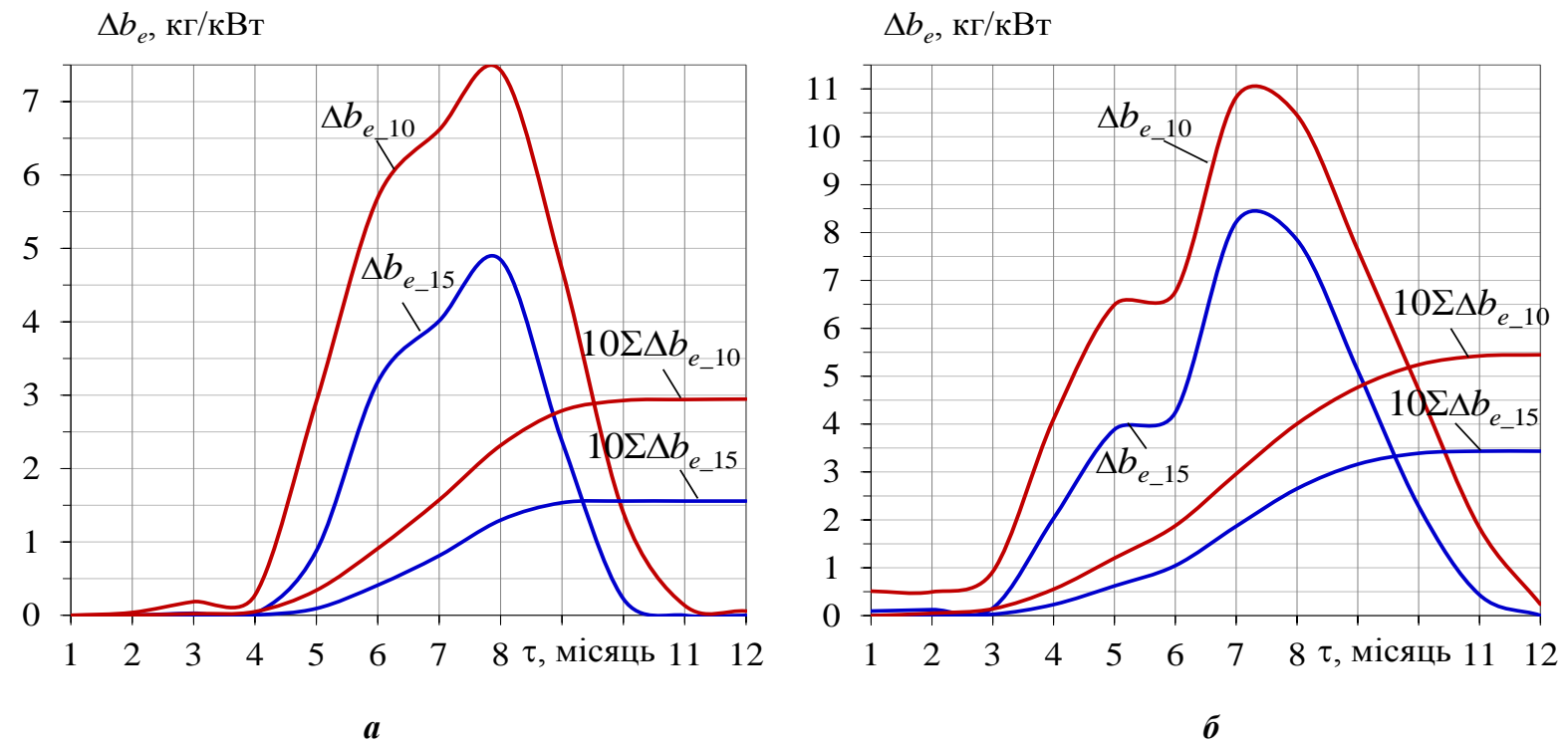

Рисунок 5 - Значення щзомісячної $\Delta b_{e} i$ загальної річної $\Sigma \Delta b_{e}$ економї палива при різних температурах

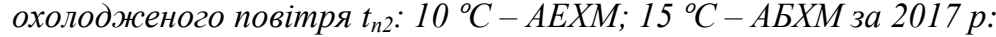
$\boldsymbol{a}$-м. Одеса, Украӥна; б-м. Чженьизян, провінція Цзянсу, КНР

Як видно 3 рис. 5, охолодження повітря на вході ГТУ потужністю $10 \mathrm{MB}$ до температури $15^{\circ} \mathrm{C}$ в АБХМ забезпечує річну питому економію палива $\Sigma \Delta b_{e 15}$ близько 15 кг/кВт (на 1 кВт потужності ГТУ) для умов м. Одеса (рис.5, a), тоді як для вологого клімату м. Чженьцзян (рис.5, б) - близько 35 кг/кВт. В той же час більш глибоке охолодження повітря в АЕХМ до $10{ }^{\circ} \mathrm{C}$ дає змогу отримати набагато більшу питому економію палива за рік $\Sigma \Delta b_{e 10}: 30$ кг/кВт (рис. 5, a) і близько 55 кг/кВт (рис.5, б) відповідно.

Звертає на себе увагу значне збільшення питомої річної економії палива $\Sigma \Delta b_{e 10}$ за рахунок більш глибокого охолодження повітря на вході ГТУ в АЕХМ до температури $t_{\text {п2 }}=10^{\circ} \mathrm{C}$ порівняно з його охолодженням в АБХМ до $t_{\text {п2 }}=15^{\circ} \mathrm{C}$, майже вдвічі для кліматичних умов м. Одеса та у півтора рази для субтропічного клімату м. Чженьцзян. Варто зазначити, що через витрати потужності ГТУ, відповідно й палива, на подолання аеродинамічного опору повітроохолоджувача на вході реальна економія палива буде дещо меншою.

\section{3. Висновки}

Встановлено, що за рахунок більш глибокого охолодження повітря на вході ГТУ в АЕХМ до температури $10^{\circ} \mathrm{C}$ порівняно з його охолодженням в АБХМ до $15^{\circ} \mathrm{C}$ питома річна економія палива майже вдвічі більше для кліматичних умов півдня України та у півтора рази - для субтропічного клімату КНР.

Показано, що більш глибоке охолодження повітря на вході ГТУ до температури $10^{\circ} \mathrm{C}$ в АЕХМ забезпечує зменшення витрати палива завдяки взаємно пов'язаному подвійному ефекту: збільшенню самої величини зниження температури повітря $\Delta t_{10}$ до $10^{\circ} \mathrm{C}$ за рахунок обумовленого нею ж зростання тривалості охолоджувального сезону на $20 . .30 \%$ порівняно 3 традиційним охолодженням повітря до температури $15^{\circ} \mathrm{C}$ в АБХМ.

\section{Література}

1. De Sa, A. Gas turbine performance at varying ambient temperature [Text] / Ashley De Sa, Sarim Al Zubaidy // Applied Thermal Engineering. - 2011. - № 31. - pp. 27352739.

2. Ghaebi, H. Integration of an absorption chiller in a total CHP site for utilizing its cooling production potential based on R-curveconcept [Text] / H. Ghaebi, Sh. Karimkashi, M.H. Saidi // International journal of refrigeration. - 2012. - V.35 - pp. 1384-1392.

3. Erdem, H. H., Sevilgen S. H., Case study: Effect of ambient temperature on the electricity production and fuel consumption of a simple cycle gas turbine in Turkey // Applied Thermal Engineering. - 2006. - №26. - pp. 320 326.

4. Радченко, А. Н. Метод выбора рациональной тепловой нагрузки абсорбционно-эжекторного термотрансформатора охлаждения воздуха на входе регенеративных ГТУ компрессорных станций [Текст] / А. Н. Радченко, С. А. Кантор // Авиационно-космическая техника и технология. - 2015. - № 5(122). - С. 61 - 64 .

5. Радченко, А. Н. Методологический подход к рациональному проектированию комбинированной теплоиспользующей системы охлаждения воздуха на входе газотурбинной установки [Текст] / А. Н. Радченко, С. А. Кантор // Авиационно-космическая техника и технология. - 2015. - № 4(121). - С. 76 - 79.

6. Nikolaev gas turbines for industrial applications // Nikolaev: State Enterprise NPKG "Zarya" - "Mashproekt", 2004, 19 p. 


\title{
Analyzing the fuel efficiency of gas turbine unite inlet air cooling for different climatic conditions
}

\author{
A. N. Radchenko ${ }^{1}$, Y. Zongming ${ }^{2}$, S. A. Kantor ${ }^{3}$, B. S. Portnoi ${ }^{1}$ \\ ${ }^{1}$ Admiral Makarov National University of Shipbuilding, Mykolaiv, Ukraine \\ ${ }^{2}$ Jiangsu University of Science and Technology, Zhenjiang, China \\ ${ }^{3}$ PJSC "Zavod "Ekvator", Mykolaiv, Ukraine
}

\begin{abstract}
The fuel efficiency of deep cooling the air at the entrance of the gas turbine plant in climatic conditions of southern Ukraine (the region of Odessa) and the subtropical climate of the People's Republic of China (for example, Zhenjiang, Jiangsu Province) have been analyzed. For this the efficiency of two-stage air cooling at the inlet of the gas turbine plant was investigated: the precooling of the ambient air by cold water with a temperature of $7^{\circ} \mathrm{C}$ from the absorption lithium-bromide chiller to the temperature of $15{ }^{\circ} \mathrm{C}$ in the first high-temperature air cooler stage and the subsequent deeper cooling down to the temperature of $10^{\circ} \mathrm{C}$ in the second low-temperature stage by boiling refrigerant from an ejector refrigeration chiller as constructively the most simple and reliable in operation. With this as an lithium-bromide chiller, and an ejector refrigeration chiller uses the heat of the exhaust gases from the gas turbine installation for generation of refrigeration capacity. A specific fuel consumption is applied as a criterion. The efficiency of deep cooling at the inlet of gas turbine unite was analyzed by the current values of the reduction in specific fuel consumption according to changing climatic conditions of operation during the year, and by the monthly and annual fuel saving. It is shown that deeper cooling of air at the inlet of GTU to the temperature of $10^{\circ} \mathrm{C}$ in absorption-ejector chiller (AECh) provides a reduction in the fuel consumption from one and a half to two times due to a mutually coupled dual effect: an increase in the air temperature decrease $\Delta t_{10}$ and increase in the duration of the cooling season by 20-30\% compared with the traditional cooling of the air to the temperature of $15^{\circ} \mathrm{C}$ in the $\mathrm{ABCh}$ coursed by the lower air temperature of $10{ }^{\circ} \mathrm{C}$ itself. The results of the analysis of the fuel efficiency of two-stage air cooling in extremely tense conditions, in particular the subtropical climate, provide grounds for expanding the geography for the large scale use of deep cooling air in regions where is the most widespread traditional air cooling in the ABCh and the use of contact methods of air cooling by injecting water does not give the desired effect because of too high air humidity.
\end{abstract}

Keywords: air cooling; chiller; gas turbine unite; climate

\section{References}

1. De Sa, A., Al Zubaidy S. (2011) Gas turbine performance at varying ambient temperature. Applied Thermal Engineering, No. 31, pp. 2735-2739.

2. Ghaebi, H., Karimkashi Sh., Saidi M.H., Ghaebi H. (2012) Integration of an absorption chiller in a total CHP site for utilizing its cooling production potential based on R-curveconcept. International Journal of Refrigeration, vol. 35, pp. 1384-1392.

3. Erdem, H. H., Sevilgen S. H. (2006) Case study: Effect of ambient temperature on the electricity production and fuel consumption of a simple cycle gas turbine in Turkey. Applied Thermal Engineering, No.26, pp. 320-326.
4. Radchenko A. N., Kantor, S. A. (2015) The method of evaluation of rational heat load on absorption-ejector thermotransformer for cooling regenerative GTU intake air of compressor stations. Aerospace technics and technology, No. 5 (122), pp. 61-64.

5. Radchenko, A. N., Kantor, S. A. (2015) Metodological aproaches of ratinal designing of combined waste heat recovery system for gas turbine unit intake air cooling. Aerospace technics and technology, No. 4 (121), pp. 76-79. 6. Nikolaev gas turbines for industrial applications. Nikolaev: State Enterprise NPKG "Zarya"-"Mashproekt", 2004, 19 p.

Received 08 October 2018 Approved 04 December 2018 Available in Internet 30 December 2018 